9. Plisko, V.I., Bosenko, A.I., \& Bondarenko, V.V. (2018). Motivational-value criterion of professional readiness of future patrol police officers. Naukovyi chasopys Natsionalnoho pedahohichnoho universytetu imeni M.P. Drahomanova, Scientific journal of the National Pedagogical University named after M.P. Dragomanov. 8(102)18, 50-56 (in Ukr.).

10. On National Police. Law of Ukraine from July 2, 2015, No. 580-VIII. Retrieved from http://zakon2.rada.gov.ua/laws/show/580-19 (in Ukr.).

11. Ridei, N.M. (2011). Theory and practice of step-bystep training of future ecologists. Extended abstract of Doctor's thesis. Kyiv (in Ukr.).

12. Simko, R.T. (2011). Psychological training and readiness of the police officers to professional activities. Problemy suchasnoi psykholohii, Problems of modern psychology, 12, 777-786. Retrieved from http:// problemps.kpnu.edu.ua/wp- content/uploads/sites/58/2017/06/12-75.pdf (in Ukr.).

13. Yavorska, H.Kh., \& Rudnytskyi, V.Ye. (2013). Professional readiness to perform atypical situations at the personnel of the special unit of the Ministry of Internal Affairs of Ukraine. Nauka i osvita, Science and education. 1-2, 241-244 (in Ukr.).

14. Prontenko, K., Andreichuk, V., \& Martin, V. (et al.). (2016). Improvement of Physical Preparedness of Sportsmen in Kettlebell Sport on the Stage of the Specialized Base Preparation. Journal of Physical Education and Sport. 16(2), 540-545. Retrieved from http://efsupit.ro

15. Prontenko, K., Klachko, V., \& Bondarenko, V. (et al.). (2017). Technical Preparedness of Sportsmen in the Kettlebell Sport. Journal of Physical Education and Sport. 17(1), 28-33. Retrieved from http://efsupit.ro.

\title{
ПРОНТЕНКО Костянтин,
}

доктор педагогічних наук, доцент, доцент кафедри фізичного виховання, спеціальної фізичної підготовки і спорту,

Житомирський військовий інститут імені С. П. Корольова

ПМІСКО Вамерій,

доктор педагогічних наук, професор, професор кафедри педагогіки, психології і методики фізичного виховання Національний університет "Чернігівський комегіум» імені Т. Г. Шевченка

\section{ГРИБАН Григорій}

доктор педагогічних наук, професор, завідувач кафедри фізичного виховання та рекреації, Житомирський державний університет імені Івана Франка

\section{БОНДАРЕНКО Ваऽентин,}

кандидат педагогічних наук, доцент, завідувач кафедри спеціальної фізичної підготовки Національна академія внутрішніх справ

\section{ЕТАПИ ФОРМУВАННЯ ПРОФЕСІЙНОЇ ГОТОВНОСТІ ПРАЦІВНИКІВ ПІДРОЗДІАІВ} ПАТРУАЬНОЇ ПОАІЦЇ̈ ТА ПОАІЦІї ОХОРОНИ

\begin{abstract}
Анотаиія. У статті теоретично обтрунтовано етапи формування професійної готовності праиівників підрозділів патрульної поліиї та поліиї̈ охорони. В дослідженні взяли участь працівники управлінь патрульної поліиї та поліиї охорони Київсъкої та Житомирсъкої областей (n=92).

Проаналізовано наукову літературу та нормативні документи, шо регламентують профресійне навчання прачівників Наиіональної поліиії України. З'ясовано, ијо професійна готовність праиівника поліиї - ие стан особи, який дає змогу здійснювати службову діяльність на належному професійному рівні й інтегрує компоненти професійної готовності зі спроможністю оперативно їх поєднувати, постійно оновлювати, накопичувати й розвивати.
\end{abstract}

На підставі здійснених досліджень виокремлено етапи формування професійної готовності праиівників поліиї: етап професійного самовизначення, професійного становлення та професійного зростання. Установлено невідповідність рівня професійної готовності праиівників патрульної поліиії та поліиї охорони вимогам криміногенної ситуаиї̈ в країні.

ключові слова: Наиіональна поліиія; патрульна поліиія; поліиія охорони; професійна готовність; професійне навчання; службова підготовка.

Одержано редакиією 17.01.2019 Прийнято до публікаиї̈ 21.01.2019

DOI $10.31651 / 2524-2660-2019-2-104-110$

ORCID ID 0000-0003-1496-2465

\section{НEBЗОРОВ Роман Вiкторович,}

старший викладач кафедри мьотної експлуатації і бойового застосування мітаків, Харківський національний університет Повітряних Сим імені Івана Кожедуба e-mail: roman_nevzorov@ukr.net

УДК 378.1:355.232.2

\section{ФАХОВА КОМПЕТЕНТНІСТЬ МАЙБУТНІХ ВІЙСЬКОВИХ ПІАОТІВ}

У статті представлено результати теоретичного аналізу проблеми фахових компетениій майбутніх війсъкових пілотів. З'ясовано, шо у психологічній науиі розмежовують такі поняття як "компетениія" та "компетентність", під компетениією розуміють деяку відчужену, наперед задану вимогу (норму) до освітньої підготовки особистості; компетентність - ие володіння відповідною компетениією, шјо охоплює особистісне ставлення до неї та пред- мета діяльності. Зазначено, шо до професійних компетентностей, які повною мірою притаманні й випускникам льотних навчальних закладів відносяться: иіннісно-мотиваиійна готовність, інтелектуальна підготовленість, діяльнісні здібності, професійні та фахові здібності, суб'єктна компетентність.

Ключові слова: компетентність; фрахова компетентність; компетениія; формування фахових компетентностей. 
Постановка пробцеми. В сучасних умовах розвитку Збройних Сим України, державі потрібні інтелектуально та професійно підготовлені військові фахівці, які володіють сучасними формами та видами збройної боротьби; здатні на всіх етапах своєї службової кар'єри здобувати нові знання; керувати військами (силами) в бою (операції); організовувати навчання, виховання, моральнопсихологічну підготовку особового складу в мирний та воєнний час, діяти в ризиконебезпечних ситуаціях; експлуатувати й застосовувати найскладніші системи озброєння та військової техніки.

Автори наукових праць останніх років висвітлюють різні аспекти проблеми формування фахових компетентцій майбутніх фахівців (В. Байденко, О. Бирюк, I. Галяміна, О. Задорожна, I. Зимня, М. Аевочко, О. Овчарук, П. Онипченко, I. Родигіна, Н. Савченко, Г. Селевко, Ю. Татур, В. Ягупов та ін.). Аналіз досліджень спонукає до висновку про відсутність єдиного підходу до розуміння сутності терміна "компетентність" і поняття "формування фахових компетенцій".

Проводились певні дослідження 3 проблем підготовки фахівців до професійної діяльності, у тому числі й пілотів, формуванню у них навичок пілотування та контролю за ї набуттям. Результати цих досліджень стосуються таких проблем, як професійний відбір пілотів та інших авіаційних фахівців (Т. Джамгаров, С. Мімерян, В. Небиліцин, К. Пцатонов, Б. Теплов, В. Трошин та ін.), формування професійної придатності (О. Деминський, Є. Клімов, В. Маріщук та ін.), професійної підготовки фахівців (С. Бочарова, М. Дьяченко, О. Коваленко, Р. Раєвський, О. Романовський та ін.), педагогічних основ професійної підготовки цьотного складу (П. Картамишев, Р. Макаров, О. Тарасов та ін.), психічних особливостей (Н. Завалова, Б. Аомов, В. Маріщук, К. Пцатонов, Б. Покровський, В. Пономаренко та ін.).

Аналіз вітчизняної та зарубіжної $\Lambda$ тератури за останні 20 років свідчить, що проблема підготовки майбутніх військових пілотів до виконання бойових завдань, а саме: формування навичок виконання різних видів бойових польотів, як найскладніших, багатоелементних процесів, у майбутніх військових пілотів та їх контроль залишається недостатньо розробленою та засвідчує, що проблема підготовки майбутніх військових пілотів із застосуванням засобів повітрянотактичної підготовки не була предметом спеціального вивчення.

Мета статті - здійснити теоретичний аналіз проблеми фахових компетенцій майбутніх військових пілотів.

Виклад основному матеріалу дослідження. Наразі є необхідність в інтелектуально-розвинених і професійнопідготовлених військових фахівців, які досконало володіють сучасними формами та видами збройної боротьби, здатні на всіх етапах своєї службової кар'єри здобувати нові знання, керувати військами (силами) в бою (операціі), працювати з особовим складом в мирний та воєнний час, адекватно діяти в небезпечних ситуаціях тощо.

Реалізація зазначених напрямів, насамперед, пов'язана 3 формуванням модемей і змісту підготовки військових фахівців, зокрема пікотів, що мають розроблятися на системних, компетентнісних засадах і враховувати такі чинники та складові: національні інтереси, націонамьну безпеку держави, психологічні уявмення щодо характеру та структури військово-професійної діяльності; вимоги до військового фахівця, навчальна діяльність якого базується на здобутті компетенцій, продукуванні знань; структуру поетапного розвитку тих, хто навчається.

Розглядаючи сутність поняття "професійна діяльність", чинників ії ефективності та результативності, науковці у різний час по-різному характеризували поняття "Високий рівень досягнень". Упродовж останніх десятиліть у дидактичній мітературі набули широкого поширення терміни "компетентність" i "компетенція". Над визначенням цих понять працюють учені різних галузей знань (Аінгвісти, соціолінгвісти, Аінгвокуцьтурознавці, психологи, педагоги), на більш загальному рівні - міжнародні освітні організації.

Вітчизняні та зарубіжні науковці гостро дискутують щодо визначення основних понять "компетентність" i "компетенція", одні з них ї ототожнюють, інші диференціюють. У більшості зарубіжних досліджень, що з'явилися за останні 5-7 років (Cl. Beelishe, M. Linard, B. Rey, L. Turkal, M. Joras та ін.), поняття "компетенція" трактується не як сукупність здібностей, умінь і навичок, а як здатність чи готовність мобілізувати всі ная- 
вні ресурси (охоплює знання, уміння, навички, здібності та психологічні якості), потрібні для виконання завдання на високому рівні у конкретній педагогічній ситуації.

Сучасна педагогічна теорія і практика пропонує розуміти поняття "компетентності" як актуальний вияв компетенції. Опрацювання наукової мітератури з цієї проблеми показало, що одні вчені ототожнюють ці два поняття, а інші - неодмінно розмежовують. Дия розкриття змістовної сутності поняття "фахова компетентність військових пілотів" слід зосередитися на особливостях понять "компетенція" та "компетентність".

Поняття "професійна компетентність" 3'явилося у 80-х роках $\mathrm{XX}$ століття і як термін уперше вживається у працях Ю. Бабанського [1], В. Сластьоніна [2], які вважали його скмадовою професіонамізму фахівця.

Так, компетентність у науковій $\Lambda$ ітературі трактується як здатність ухвалювати рішення і нести відповідальність за ïx реалізацію під час виконання функціональних обов'язків, як не тільки професійні знання, навички та досвід, а й ставлення до справи, визначені (позитивні) схимьності, інтереси і прагнення, здатність ефективно використовувати знання й уміння, а також особистісні якості дмя забезпечення потрібного результату на конкретному робочому місці у конкретній робочій ситуації, як інтегральна якість особистості, яка проявляється в іiі загальній здатності та готовності до діямьності, що грунтується на знаннях і досвіді, які набуті в процесі навчання і соціалізації та орієнтовані на самостійну й успішну діяльність, як володіння відповідним рівнем компетенції, особистісне ставцення до цієї компетенції та предмета діяльності [3].

Вітчизняні вчені по-різному тиумачать поняття "компетентність". Найбільшого поширення в науковій мітературі набуло визначення компетентності як "сукупності знань і умінь, необхідних дия ефективної професійної діяльності (уміння аналізувати, передбачати наслідки професійної діяльності, використовувати інформацію)".

А. Хуторський розмежовує поняття "компетенція" та "компетентність". Під компетенцією він розглядає "відчужену, наперед задану вимогу (норму) до освіт- ньої підготовки особи", наявність певних якостей особистості, сукупність знань, умінь, навичок, що необхідні для ефективної діяльності. Компетентність, на його думку, це "володіння відповідною компетенцією, що охоплює особистісне ставцення до неї та предмета діяльності». Поняття "компетентність", вважає автор, включає не тільки когнітивні та операціонально-технологічні, а й мотиваційні, етичні, соціальні та поведінкові скмадові, а також результати навчання (знання та вміння), систему ціннісних орієнтацій, звички тощо [3].

У дослідженнях І. Зимньої компетентність розглядається як сукупність трьох аспектів: змістового (осмислення ситуації в загальному культурному контексті, тобто в контексті наявних кумьтурних зразків розуміння, ставлення, оцінки); проблемно-практичного (забезпечує адекватну оцінку ситуації, постановку та ефективне виконання конкретних завдань); комунікативного (активізує увагу на адекватному спілкуванні в конкретних ситуаціях культурного контексту з урахуванням відповідних прикладів спілкування і взаємодії) [4]. Таким чином, компетентність передбачає наявність якостей, які забезпечать ефективну професійну діяльність у конкретних умовах.

В. Беспалько вважає, що професійна компетентність охоплює систему вмінь і навичок фахівця, його ціннісні орієнтації, мотиви діяльності, інтегровані показники культури (мова, стиль, спілкування, став ення до себе і своєї діяльності, до суміжних галузей знань). Фахівця характеризує високий ступінь автономії та креативності, що виявляється разом із високим рівнем професійної компетентності в таких "ділових якостях", як гнучкість професійного мислення, мобільність і спроможність адаптуватися до інноваційних ситуацій професійної діяльності, постійне професійне самовдосконалення, здатність працювати в команді, співпрацювати 3 іншими, брати на себе ініціативу та відповідамьність [5].

В окремих роботах зустрічаються поняття "компетентність" і "група компетентностей". Практично одним словом ми визначаємо і загальну здатність, кінцевий результат та компоненти, тобто складові групи компетентностей. У цьому випадку можна підкреслити професійну 
компетентність мюдини, а можна виокремити конкретні складові, які зазвичай iii визначають. Також можна підкреслити, що обидва ці поняття відображають цілісність та інтегративну сутність результату навчання на будь-якому рівні та в будь-якому аспекті. Відтак складність, скомбінованість цього педагогічного явища зумовлює виокремлення певних структурних елементів поняття "компетентність" і розмежування понять "компетенція" та "компетентність".

Р. Гільмєєва вважає, що поняття "професійна компетентність" охоплює три блоки якостей особистості: професійно-особистісний, пов'язаний із засвоєнням і розвитком професійних умінь $\mathrm{i}$ навичок, інтелектуального потенціалу, емоційно-вольової сфери; професійнодіяльнісний, пов'язаний із розвитком особистості та створенням умов дмя їі саморозвитку; професійно-творчий, що визначає готовність педагога сприймати та реалізувати інноваційні ідеї, нову інформацію й уміння оволодівати сучасними технологіями [6].

Аналіз наукових доробок надав змогу систематизувати класифікацію компетентностей:

- ключові (соціальна, комунікативна, використання інформаційних техномогій, робота в команді, самоосвіта тощо);

- за видами діяльності (трудова, навчальна, комунікативна, професійна, предметна, профільна, фахова тощо);

- за сферами суспільного життя (побутова, мистецька, спортивна, політична тощо);

- знаннєва (математична, фізична, гуманітарна, хімічна тощо);

- за галузями суспільного виробництва (військова, інженерна, економічна, технологічна, педагогічна тощо);

- за складниками психічної діяльності Аюдини (когнітивна, технологічна, мотиваційна, соціальна, поведінкова тощо);

- за напрямом вияву здібностей (спортивна, когнітивна, суспільна, виконавча, творча, художня, технічна тощо);

- за ступенями соціального розвитку й статусу (готовність до вищої школи, компетентності випускника, бакалавра, спеціаліста, магістра, керівника тощо).
Т. Аевочко репрезентує такі види компетентності: навчально-пізнавальна, інформаційна, комунікативна, соціально-трудова, компетенція особистісного самовдосконалення та професійна компетенція [7].

В. Ягупов пропонує дещо іншу кмасифікацію: кАючові компетентності, професійні компетентності та фахові компетентності [8].

На нашу думку, професійні компетентності, які повною мірою притаманні й випускникам мьотних навчальних закладів, можна представити наступними складовими:

- ціннісно-мотиваційна готовність, тобто сформованість професійних і фахових ідеалів, цінностей, настанов, мотивів і ставлень особистості до майбутньої професії та фаху, до самої себе як до професіонала і фахівця;

- інтелектуальна підготовленість (когнітивна характеристика), тобто набуття певної сукупності теоретичних i практичних знань, на основі яких відбувається, з одного боку, формування праксеологічної основи професійної діяльності, а з іншого - практичного мислення фахівця;

- діяльнісні здібності (праксеологічна характеристика) - це сукупність професійних практичних навичок, умінь i здібностей, необхідні для професійної діяльності;

- професійні та фахові здібності це сукупність професійно важливих i фахових якостей, що необхідні для професійної діяльності особи як професіонама та фахівця;

- суб'єктна - це інтегральна характеристика, оскільки вона об'єднує всі зазначені вище аспекти в унікальне єдине ціле, характерне тільки дмя конкретної особи та конкретного фахівця, а 3 іншого боку, від ії сформованості залежить актуалізація таких аспектів, як інтелектуального, діяльнісного, професійного та фахового, а також професійне становлення та професійна діяльність особи як професіонала й фахівця.

Названі характеристики взаємодоповнюють одна одну, сприяють їхньому комплексному та системному вияву, за необхідності можуть компенсувати недостатню сформованість певних показників професійної компетентності фахівця. 
За недостатньої сформованості одного 3 них фахівець неспроможний досягати основної мети своєї професійної діяльності, системно й комплексно реалізовувати основні посадові компетенції. Проте суб'єктний компонент здатний декомпенсувати певні недоліки окремих компонентів професійної компетентності.

Отже, професійна компетентність $€$ найважливішою компетентністю в проекції на тематику нашого дослідження.

Як зауважує Г. Стайнов, суттєвими ознаками професійної компетентності слугує сукупність інтегральних критеріїв, зумовлених комбінацією таких складників: система знань, їхня глибина та широкий діапазон, постійне прагнення вчитися й оновлювати власні знання, наявність зацікавленості науковими дослідженнями, гнучкість мислення, комунікабельність, культура, діалектичне мисмення, володіння методами аналізу, синтезу, порівняння, наявність абстрактного, системного мислення, просторової уяви, творчого ставлення до професійної діяльності, здатність сміливо ухвалювати рішення в нестандартних ситуаціях, готовність і прагнення до професійного самовдосконалення, спроможність швидко адаптуватися до зміни технології, організації та умов праці [9].

Основними видами професійної компетентності Т. Шамова вважає: спеціальну (фахову), яка пов'язана з безпосередньою управлінською діяльністю; соціальну - реалізовану в умінні працювати, організовувати спільну діяльність колективу дмя досягнення мети, брати на себе відповідальність за спільні результати; та особистісну - здатність до саморозвитку, самовдосконалення, самореалізації, прагнення до постійного підвищення вцасної освітньої компетентності, уміння організувати свою працю та овомодіння мідерськими якостями разом із харизмою [10].

О. Петрук поділяє професійну компетентність на чотири основні рівні [11]:

- фахова компетенція - знання, уміння, навички, досвід, необхідні для виконання певних службових завдань;

- дімова компетенція - організованість, ініціативність, ефективність, працьовитість, що сприяють реалізації службових завдань;
- морально-психологічна компетенція - самооцінка, справедливість, об'єктивність, культура поведінки як необхідний чинник самоорганізації фахівця;

- інтелектуальна компетенція - загальна ерудиція, уміння аналізувати явища в різних сферах життя, володіти методологією та навичками ухвалення оптимального рішення.

Нам імпонує запропонована науковцем В. Ягуповим структура професійної компетентності фахівця:

- загальнолюдська компетентність (загальнокультурна, моральна, політична, соціальна, інформаційна, комунікативна, етична, екологічна, валеологічна);

- загальнонаукова компетентність (методологічна, теоретична, методична, дослідницька);

- загальнопрофесійна компетентність (загальнофахова, економічна, технічна, правова, психологічна, педагогічна);

- фахова компетентність (технологічна);

- функційна компетентність (стратегічна, менеджерська, управління суб'єктами та об'єктами діяльності, виконавська);

- особистісна компетентність (мотиваційна, аутопсихологічна, регулятивна, адаптивна, навчальна) [8].

Спеціальність конкретизує вузьке та менш стійке коло робіт у межах однієї базової професії та може бути диференційована на підтипи й групи споріднених спеціальностей. Синонімічний ряд українського варіанту значень понять "професія" i "спеціальність" доповнений близьким терміном "фах". У “Новому тлумачному словнику української мови" "фах" витлумачено: 1) вид заняття, трудової діяльності, що вимагає певної підготовки та $€$ основним засобом до існування; професія; спеціальність, кваліфікація; будь-який вид занять, що $є$ основним засобом до існування; 2) основна кваціфікація, спеціальність; справа, заняття, у якому хтось виявцяє велике вміння, майстерність, хист. Водночас "фахівець"- це 1) той, хто досконало володіє якимось фахом, має високу кваліфікацію, глибокі знання з певної галузі науки, техніки, 
мистецтва тощо; 2) той, хто зробив якесь заняття своєю професією [12].

У психомого-педагогічній мітературі поняття "фахова компетентність" практично не застосовують. Аише окремі науковці послуговуються ним у своїх працях. Загалом поняття "фахова компетентність" має різне трактування:

- підготовленість до виконання трудової діяльності за конкретною спеціалізацією в межах певної спеціальності;

- набір фахових знань персоналу організації, що необхідні для розв'язання соціально-економічних, політичних, екомогічних, культурологічних, правових та інших проблем у межах цілей, поставмених перед організацією;

- здатність до освітньої діяльності на основі здобутих знань та сформованих умінь відповідно до суспільних вимог і ціннісних орієнтацій;

- системна властивість особистості вчителя, що передбачає володіння фаховими компетентностями, здатність застосовувати набуті знання та вміння в професійній діяльності, можливості досягати значних результатів в організації процесу навчання математики;

- сукупність знань, умінь, здібностей і готовності особистості діяти в складній ситуації та розв'язувати фахові завдання $з$ високим рівнем невизначеності;

- актуалізована здатність і готовність фахівця творчо реалізовувати цілі своєї фахової діяльності;

- важлива характеристика практичної та теоретичної підготовменості фахівця до професійної діяльності;

- інтегральна професійно особистісна характеристика фахівця, що охоплює теоретичну і практичну готовність до виконання професійних функцій.

Дослідники пропонують різні класифікації фахової компетентності, однак, незалежно від форм діяльності фахівця, компетентність передбачає два основні компоненти: систему знань, яка демонструє теоретичну готовність фахівця; систему вмінь і навичок, що становить підгрунтя практичної готовності фахівця до професійної діяльності.

Проаналізувавши та систематизувавши погляди науковців щодо означеного питання, під фаховою компетентністю майбутніх військових пілотів ми розуміємо сукупність загальнонаукових, загацьноавіаційних і спеціальних знань, умінь, навичок, морально-вольових, фізичних і психофізіологічних якостей, що детермінують ефективне виконання виробничих функцій та типових завдань діяльності на засадах перманентної самоосвіти й самовдосконалення.

Висновки та перспективи подальших досліджень. Фахова компетентність майбутнього військового пілота - скмадне системне утворення, основними елементами якого $€$ підсистема професійних знань, як могічна системна інформація, зафіксована у свідомості; підсистема професійних умінь як психічних утворень, що полягають у засвоєнні мюдиною способів і технік професійної діяльності; підсистема професійних навичок - дії, що сформовані в процесі повторення певних операцій і доведені до автоматизму; підсистема морально-ціннісних позицій, як сукупність сформованих установок і орієнтацій, ставцення й оцінок внутрішнього й навколишнього досвіду, реальності, які визначають характер професійної діяльності та поведінки фахівця; підсистема індивідуальнопсихологічних особливостей фахівця поєднання різних структурнофункціональних компонентів психіки, які визначають індивідуальність, стиль професійної діяльності, поведінки і виявмяються у професійних якостях особистості, які зумовлюють потребу фахівця в постійному саморозвитку, творчості та самовдосконаленні.

Подальше наше дослідження буде зосереджене на виокремленні необхідних організаційно-педагогічних умов формування фахової компетентності майбутніх військових пікотів.

\section{Список бібліографічних посимань}

1. Бабанский Ю. К. Оптимизация педагогического процесса. Київ: Радянська школа, 1982. 198 с.

2. Сластенин В. А., Подымова А. С. Педагогика: инновационная деятельность. М.: Магистр, 1997. 308 c.

3. Хуторской А. В. Кцючевые компетенции как компонент мичностно-ориентированной парадигмы образования. Народное образование. 2016. № 2. C. 58-64.

4. Зимняя И. А. Ключевые компетенции - новая парадигма результата образования. Высшее образование сегодня. 2003. № 5. С. 34-42.

5. Беспалько В.П., Татур Ю.Г. Системнометодическое обеспечение учебновоспитательного процесса подготовки специалистов. М.: Высшая школа, 1989. 158 с. 
6. Гильмеева Р. Х. Развитие профессиональной компетентности учителя в системе повышения квамификации. Методист. 2002. № 5. С. 6-8.

7. Мевочко М. Т. Професійна підготовка майбутніх фахівців економічної галузі: теорія, методика, організація: монографія. Київ: Держ. акад. статистики, обліку і аудиту, 2009. 495 с.

8. Ягупов В. В. Провідні методологічні характеристики основних видів компетентності майбутніх фахівців, що формуються в системі професійнотехнічної освіти. Модернізаиія професійної освіти і навчання. Київ. 2012. Вип. 2. С. 45-59.

9. Стайнов Г. Н. Педагогическая система преподавания общетехнических дисциплин. М.: Педагогика, 2002. 136 с.

10. Шамова Т. И. Система последипломного образования руководителей образовательных учреждений: опыт, проблемы, перспективы. Педагогическое образование и наука. 2004. № 3. С. 3-9.

11. Петрук О. М. Банківська справа: навч. посіб. За ред. Ф. Ф. Бутинця. Київ: Кондор, 2004. 461 с.

12. Новий тлумачний словник української мови: у 3-х т. / упоряд.: В. В. Яременко, О. М. САіпушко. Київ: AKOHIT, 2006. 926 с.

\section{References}

1. Babansky, Yu.K. (1982). Optimization of the pedagogical process. Kiev: Soviet school. 198 p.

2. Slastenin, V.A., Podymova, L.S. (1997). Pedagogy: innovation. Moscow: Master. 308 p.

3. Khutorskoy, A.V. (2016). Key competencies as a component of the personality-oriented educational paradigm. Popular education. 2. 58-64.
4. Zimnyaya, I.A. (2003). Key competencies - a new paradigm of the result of education. Higher education today. 5. 34-42.

5. Bespalko, V.P., Tatur, Yu.G. (1989) Systematic and methodological support of the educational process of training specialists. Moscow: High School. 158 p.

6. Gilmeeva, R.Kh. (2002). Development of professional competence of the teacher in the system of advanced training. Methodist. 5. 6-8.

7. Levochko, M.T. (2009). Professional training of future specialists in the economic field: theory, methodology, organization: monograph. Kyiv: State Academy of Statistics, Accounting and Audit. 495 s.

8. Yagupov, VV (2012). Leading methodological characteristics of the main types of competence of future specialists, which are formed in the system of vocational education. Modernization of vocational education and training. Kiev. 2. 45-59.

9. Steinov, G.N. (2002). Pedagogical system of teaching general technical disciplines. Moscow: Pedagogy. $136 \mathrm{p}$.

10. Shamova, T.I. (2004). Postgraduate education system for heads of educational institutions: experience, problems, prospects. Pedagogical education and science. 3. 3-9.

11. Petruk, O.M. (2004). Banking. In F.F. Butinets (Ed.). Kyiv: Condor. 461 p.

12. New explanatory dictionary of the Ukrainian language: in 3 volumes (2006). In V.V. Yaremenko, O.M. Slipushko (Compilers). Kyiv: AKONIT. 926 p.

\section{NEVZOROV Roman,}

Senior Lecturer of flight operation and combat application of the aircrafts Department, Ivan Kozhedub Kharkov National University of Air Forces

\section{PROFESSIONAL COMPETENCE OF FUTURE MILITARY PILOTS}

Abstract. Presents the results of theoretical analysis of the problem of professional competences of future military pilots in the article.

Problem. In today's conditions of development of the Armed Forces of Ukraine, the state needs intellectually and professionally trained military specialists who possess modern forms and forms of armed struggle; capable at all stages of their career to acquire new knowledge; to manage the forces (forces) in battle (operations); organize training, education, moral and psychological training of personnel in peaceful and wartime, to operate in risky situations; exploit and use the most sophisticated weapons and military equipment.

The purpose of the article is to carry out a theoretical analysis of the problem of professional competences of future military pilots.

Results: it was found that in the psychological science distinguish such concepts as "competence" and "competence", namely: under the competence are understood as some alienated, predetermined requirement (norm) for the educational training of the individual; competence is the possession of an appropriate competence that encompasses the personal attitude towards it and the subject of activity. It is noted that professional competencies that are fully inherent to graduates of flight schools include: value-motivational readiness, intellectual preparation, activity abilities, professional and professional ability, subjective competence.

Conclusions: professional competence of the future military pilot is a complex system formation, the main elements of which is the subsystem of professional knowledge as logical system information, fixed in consciousness; subsystem of professional skills as mental entities, consisting in assimilation of the person of methods and techniques of professional activity; subsystem of professional skills - actions formed in the process of repeating certain operations and brought to automatism; subsystem of moral value positions as a set of established attitudes and orientations, attitudes and evaluations of internal and external experience, realities that determine the nature of professional activity and behavior of a specialist; the subsystem of individual psychological features of a specialist is the combination of various structural and functional components of the psyche that determine the individuality, style of professional activity, behavior and are manifested in the professional qualities of the individual, which predetermine the need for a specialist in constant self-development, creativity and selfimprovement.

Further research will focus on the identification of the necessary organizational and pedagogical conditions for the formation of professional competence of future military pilots.

Keywords: competence; professional competence; formation of professional competencies.

Одержано редакиією 17.01.2019 Прийнято до публікаиї 20.01.2019 